\title{
Analisis Hukum Relaksasi Kreadit Saat Pandemi Corona Dengan Kelonggaran Kredit Berdasarkan Peraturan Otoritas Jasa Keuangan Nomor 11/POJK.03/2020
}

\author{
Dhevi Nayasari Sastradinata, Bambang Eko Muljono \\ Fakultas Hukum Universitas Islam Lamongan \\ Email corresponding author: dhevinss@unisla.ac.id/bamekom@unisla.ac.id
}

\begin{abstract}
ABSTRAK
Covid-19 sangat berdapak dalam perekonomian Indonesia. pemerinta menetapkan Covid-19 sebgai bencana nasional non alam. Penerapan social distancing sebagai penanggulangan penyebaran virus Covid-19, namun dampak dari social distancing ini adalah melemahnya perekonomian Indonesia. Karena penurunan pendapatan menyebabkan banyak pekerja di PHK, banyaknya karyawan berkerja di rumah menyebabkan turunnya juga pendapatan masyarakat lain seperti gojek. Inisiatif pemerintah dalam mengeluarkan kebijakan untuk menanggulangi sektor ekonomi masyarakat dengan cara restuktrurisasi kredit perbankan. Hal ini berupa peringanan terhadap masyarakat yang mempunyai kredit. Dalam peringanan ini debitrur harus melakukan permohonan terlebih dahulu. Dalam restrukturisasi kredit perbankan ini dalam pengabulan permohonan diutaman untuk UMKM. Dalam pelaksanaannya hanya bank negeri saja bank swasta tidak karena tidak ada penambahan modal dari pemerintah sehingga bank swasta pun terkena dampak.
\end{abstract}

Kata Kunci: Relaksasi Kreadit, Pandemi Covid-19, Kelonggaran Kredit

\section{PENDAHULUAN}

Negara Indonesia adalah salah satu negara berkembang dengan tujuan utama yaitu untuk menciptakan kesejahteraan yang merata bagi seluruh lapisan masyarakat. Pertumbuhan ekonomi nasional merupakan salah satu faktor penting yang dapat dilakukan untuk mencapai tujuan tersebut. Pertumbuhan ekonomi yang optimal dan upaya untuk menurunkan angka kemiskinan menjadi tantangan tersendiri bagi Indonesia.

Sektor perbankan memiliki kedudukan sentral terhadap perkembangan perekonomian suatu negara. Hal ini tidak lepas dari peran strategis bank sebagai lembaga intermediasi. Peran tersebut ditegaskan dalam Pasal 3 Undang-Undang Nomor 7 Tahun 1992 tentang Perbankan sebagaimana telah diubah dengan UndangUndang Nomor 10 Tahun 1998 (selanjutnya disebut dengan UU Perbankan) yang menyatakan fungsi utama perbankan Indonesia menghimpun dan penyalur dana masyarakat. Bank mempunyai tujuan utama dalam transaksi berupa meningkatkan taraf hidup masyarakat. Dengan memfasilitasi masyarakat untuk menghimpun dana berbentuk simpanan. Simpanan tersebut dapat disalurkan kepada masyarakat lain berbentuk kredit atau lainnya. 
Dalam rangka menjalankan fungsinya sebagai penyalur dana masyarakat (financial intermediary), bank memiliki fasilitas berupa kredit. Fasilitas kredit merupakan produk bank yang paling diminati oleh masyarakat dalam upaya memenuhi kebutuhan. Sebagai efek dari globalisasi, zaman terus berkembang dan kebutuhan hidup masyarakat senantiasa terus bertambah, akibatnya sumber penghasilan terasa tidak mencukupi lagi. Masyarakat melakukan berbagai inovasi untuk membuka berbagai macam bidang usaha baru. Dalam kegiatan pengembangan usahanya, masyarakat memerlukan dana tambahan. Kredit yang disalurkan oleh bank tersebut dimaksudkan untuk memberikan tambahan dana, sehingga dapat memberikan keuntungan bagi kedua pihak.

Pemberian kredit memberikan banyak peluang untuk terciptanya lapangan kerja, karena kredit telah memberikan kesempatan bagi masyarakat untuk mengembangkan suatu usaha. Dengan demikian, tingkat pengangguran diharapkan akan berkurang. Melalui penyaluran dana kepada masyarakat, tujuan utama negara yaitu meningkatkan kesejahteraan rakyat mulai dapat tercapai dengan hadirnya banyak lapangan kerja baru tersebut. Keseluruhan aktivitas ini dilakukan sebagai upaya membantu percepatan pemerataan pertumbuhan ekonomi hingga dapat mencapai ke arah peningkatan taraf hidup rakyat banyak.

Fasilitas kredit dapat memberikan keuntungan, namun perkembangan ekonomi dipengaruhi oleh kondisi global yang penuh dengan ketidakpastian. Sesuatu yang diharapkan dapat berjalan dengan lancar, dapat terhambat oleh karena kondisi tertentu. Pada awal tahun 2020, dunia sedang dilanda oleh wabah Coronavirus Disease 2019 (selanjutnya disebut dengan Covid-19) yang penyebarannya menjadi tidak terkendali. Tak luput dari itu, sejak awal Maret 2020 pandemi Covid-19 telah memasuki wilayah Indonesia. ${ }^{1}$

Hingga akhirnya, Presiden Republik Indonesia, Ir. H. Joko Widodo menerbitkan Keputusan Presiden Nomor 12 Tahun 2020 tentang Penetapan Bencana Non-Alam Penyebaran Corona Virus Disease 2019 (Covid-19) Sebagai Bencana Nasional, pada poin nomor 1 (satu) Keputusan tersebut menyimpulkan bahwa Covid-19 yang termasuk dalam bencana non alam merupakan bencana nasional.s

Pandemi Covid-19 memberikan dampak besar pada seluruh sektor kehidupan masyarakat. Selain dampaknya di bidang kesehatan, sektor ekonomi merupakan salah satu yang paling besar merasakan dampak dari pandemi ini. Sebagai upaya untuk menahan laju penyebaran Covid-19, pemerintah menciptakan kebijakan Pembatasan Sosial Berskala Besar. Selama kebijakan tersebut berlangsung hampir seluruh aktivitas masyarakat berhenti dan akibatnya berdampak besar pada kinerja ekonomi. Ketua Tim Penanganan Covid-19 dan Pemulihan Ekonomi Nasional, Airlangga Hartarto menjelaskan terjadi kontraksi terhadap perekonomian Indonesia dan pertumbuhan berkurang sebesar 5,32 persen. Bank Indonesia memberikan 
prediksi bahwa pertumbuhan ekonomi Indonesia pada tahun ini akan tertekan di level 2,1 persen, sedangkan dalam kondisi normal mampu tumbuh mencapai 5,02 persen.

Sebagai akibat dari penurunan pertumbuhan ekonomi, hal ini berimbas juga kepada sektor perbankan. Menurut data OJK sejak Maret 2020, terjadi peningkatan jumlah kredit bermasalah. Golongan debitur yang sudah menunggak minimal 1-2 bulan (Kredit Kol-2) naik tajam menjadi 27,3 persen secara year on year. Jumlah golongan kredit tidak lancar (Kol-3) dan golongan kredit macet (Kol-5) mengalami kenaikan sebesar 19,10 persen.

Salah satu bentuk dari menurunnya sektor ekonomi tersebut, banyak anggota masyarakat termasuk debitur Bank yang kehilangan mata pencahariannya, sehingga sulit mendapatkan tambahan penghasilan agar dapat memenuhi prestasi mereka kepada Bank. Tidak dapat dipungkiri, dalam penyaluran kredit bank harus siap menghadapi risiko kredit yang menyebabkan kredit tersebut menjadi bemasalah. Pada umumnya kegiatan usaha bank mengandung banyak risiko, oleh karenanya usaha perbankan harus diatur secara ketat.

Ketika persetujuan pengembalian kredit mengalami risiko kegagalan, keadaan tersebut merupakan situasi kredit bermasalah atau Non Performing Loan (selanjutnya disebut dengan NPL). NPL merupakan tolak ukur kemampuan manajemen bank untuk mengelola kredit bermasalah yang dikeluarkan oleh bank, apabila NPL semakin tinggi, maka kualitas kredit bank akan semakin buruk dan menyebabkan jumlah kredit bermasalah bertambah besar.

Peningkatan NPL yang dialami perbankan nasional mengakibatkan bank kehilangan kemampuannya untuk menghasilkan laba yang optimum dari kegiatan operasional bank. Dana operasional bank diputar dalam bentuk kredit. Namun, akibat penyebaran Covid-19 jumlah kredit bermasalah meningkat. Dengan adanya kredit yang bermasalah tidak hanya menurunkan pendapatan bank, tetapi juga dapat mempengaruhi jumlah dana operasional dan likuiditas keuangan bank, sehingga mengganggu kesehatan bank dan akhirnya berujung pada kerugian nasabah penyimpan dana.

Agar dapat bertahan, bank harus mempertahankan tingkat profitabilitas serta tingkat likuiditas bank. Kedua hal tersebut terkait dengan kemampuan bank untuk menjalankan kewajibannya kepada para pihak yang sewaktu-waktu berkehendak untuk mencairkan atau menarik simpanannya, hal ini ditujukan agar bank tersebut dapat menjaga kepercayaan dari masyarakat.

Sebagai upaya agar bank selalu dalam keadaan sehat, liquid, solvent dan profitable, Otoritas Jasa Keuangan mengeluarkan Peraturan Otoritas Jasa Keuangan Nomor 11/POJK.03/2020 tentang Stimulus Perekonomian Nasional Sebagai Kebijakan Countercyclical Dampak Penyebaran Coronavirus Disease 2019 (selanjutnya disebut dengan POJK 11/2020). 
Setelah berlakunya POJK 11/2020, dijelaskan dalam Pasal 2 ayat (1) dan ayat (2) bahwa Bank dapat menerapkan kebijakan yang mendukung stimulus pertumbuhan ekonomi untuk debitur terdampak Covid-19 dengan cara melakukan. Pengaturan mengenai ketetapan kebijakan tentang kualitas asset dan restrukturisasi kredit. Kemudian, Pasal 5 ayat (1) menerangkan bahwa kualitas kredit atau pembiayaan yang direstrukturisasi ditetapkan lancar sejak dilakukan restrukturisasi kredit.

\section{METODE PENELITIAN}

Penelitian yuridis normatif merupakan jenis penelitian yang diguankan dalam penelitian ini. Pendekatan masalah yang digunakan dalm penelitian ini pendekatan undang-undang (Statue Approach) menelaah regulasi atau peraturan yang bersangkutan dengan isu hukum yang diteliti. Teknik pengumpulan data yang digunakan adalah studi pustaka yang bertitik berat pada substansi atau peraturan hukum yang mengatur hukum perjanjian kredit dibawah tangan pada Perbankan.

\section{TEMUAN DAN PEMBAHASAN}

\section{Analisis Hukum Relaksasi Kreadit Saat Pandemi Corona Dengan Kelonggaran Kredit Berdasarkan Peraturan Otoritas Jasa Keuangan Nomor 11/POJK.03/2020}

Dampak Vrus Corona atau Covid-19 telah berimbas pada semua sektor terutama sektor ekonomi. Berikut prediksi Bank Dunia dalam pertumbuhan ekonomi didunia terutama Indonesia, tahun ini akan di level 2,1 persen. Hal ini dampak dari meluasnya persebaran Covid-19. proyeksi Bank Indonesia (BI) mengenai pertumbuhan ekonomi rakyat Indonesia menjadi di bawah 5 persen atau hanya sekitar 2,5 persen saja yang sebelumnya mencapai 5,2 persen. Hal ini diakibatkan oleh pandemi Covid-19 sehingga pertumbuhan ekonomi melambat.

Untuk menghadapi dampak virus corona Bank Indonesia (BI) mempunyai upaya untuk menjaga stabilitas dan mendorong perekonomian nasional. Yang bertujuan mencapai pertumbuhan ekonomi yang kembali tinggi, inklusif, daan berkelanjutan, dengan stabilitas makro ekonomi maupun finansial. Namun di sisi lain, wabah ini juga menjadi dampak ekonomi yang sangat menyusahkan masyarakat terutama bagi tukang ojek, sopir taksi, dan pelaku pelaku usaha mikro kecil dan menengah (UMKM).

Menghadapi pandemi virus corona atau COVID-19 yang kini juga berimbas pada perekonomian masyarakat terutama bagi tukang ojek, sopir taksi, dan pelaku pelaku usaha mikro kecil dan menengah (UMKM) yang memiliki kewajiban membayar cicilan kepada Bank. Padahal dalam hukum perjanjian antara debitur dengan Bank telah melahirkan hubungan hutang piutang, dimana Debitur berkewajiban membayar kembali pinjaman yang telah diberikan oleh pihak Bank, dengan berdasarkan syarat, ketentuan, dan jangka waktu pembayaran yang telah 
disepakati oleh para pihak. Untuk mendapatkan kepastian bahwa debitor melunasi pinjaman maka terdapat perjanjian kebendaan ataupun perjanjian jaminan perorangan (Pasal 1154 KUH Perdata mengatur mengeni gadai, Pasal 1178 ayat (1) KUH Perdata mengatur mengenai Hipotik , Pasal 12 UU No. 4 tahun 1996 mengatur mengenai Tanggungan, Pasal 33 UU No. 42 tahun 1999 mengatur mengeni Fidusia).

Presiden Joko Widodo mempunyai inisiatif untuk memberikan kelonggaran kepada masyarakat yang berkerja non formal berupa pembayaran kredit selama 1 tahun dan penurunan bunga. Otoritas Jasa Keuangan (OJK) memberikan kelonggaran dan relaksasi kredit bagi pelaku usaha yang mempunyai nilai kredit di bawah Rp 10 miliar. Kelonggaran kredit baik yang diberikan oleh perbankan berupa:

1. Penurunan suku bunga

2. Menambah fasilitas kredit

3. Konversi kredit menjadi penyertaan modal

4. Memperpanjang waktu kredit

5. Pengurangan pokok kredit

6. Menambah fasilitas kredit dan mengurangi tunggakan bunga kredit.

Hal ini tidak semerta-merta masyarakat mendapat peringanan kredit namun harus melalui proses yang telah di tentukan OJK dan Pihak bank. Dengan cara permohonan peringanan kredit dan menyertakan dokumen-dokumen yang di perlukan.

Seperti yang terdapat dalam pasal 2 Peraturan Otoritas Jasa Keuangan Republik Indonesia Nomor 11 /POJK.03/2020 Tentang Stimulus Perekonomian Nasional Sebagai Kebijakan Countercyclical Dampak Penyebaran Coronavirus Di Sease 2019 yang berbunyi:

1) Bank dapat menerapkan kebijakan yang mendukung stimulus pertumbuhan ekonomi untuk debitur yang terkena dampak penyebaran (COVID19) termasuk debitur usaha mikro, kecil, dan menengah.

2) Kebijakan yang mendukung stimulus pertumbuhan ekonomi sebagaimana dimaksud pada ayat (1) meliputi:

a) kebijakan penetapan kualitas aset; dan

b) kebijakan restrukturisasi kredit atau pembiayaan.

3) Bank dalam menerapkan kebijakan yang mendukung stimulus pertumbuhan ekonomi sebagaimana dimaksud pada ayat (1) tetap memperhatikan penerapan manajemen risiko sebagaimana diatur dalam peraturan Otoritas Jasa Keuangan mengenai penerapan manajemen risiko Bank.

4) Dalam hal Bank menerapkan kebijakan yang mendukung stimulus pertumbuhan ekonomi sebagaimana dimaksud pada ayat (1), Bank harus memiliki pedoman untuk menetapkan debitur yang terkena dampak penyebaran (COVID-19) termasuk debitur usaha mikro, kecil, dan menengah. 
5) Pedoman penetapan debitur yang terkena dampak penyebaran 9 (COVID-19) termasuk debitur usaha mikro, kecil, dan menengah sebagaimana dimaksud pada ayat (3) paling sedikit memuat:

a) kriteria debitur yang ditetapkan terkena dampak coronavirus disease 2019 (COVID-19); dan

b) sektor yang terkena dampak (COVID-19).

Dalam pasal 2 ayat (1) Peraturan Otoritas Jasa Keuangan Republik Indonesia Nomor 11/POJK.03/2020 Tentang Stimulus Perekonomian Nasional Sebagai Kebijakan Countercyclical Dampak Penyebaran Coronavirus Di Sease 2019 ini, menyebutkan bahwa bank dapat menerapkan peraturan untuk mendukung pertumbuhan ekonomi debitur yang terkena dampak penyebaran (COVID-19) termasuk debitur usaha mikro, kecil, dan menengah. Dari kata dapat dalam pasal 2 ayat (1) ini mengandung penafsiran bahwa pasal ini bukan mewajibkan, melainkan memberikan pilihan dapat atau tidak dapat memberikan kelonggaran kepada debitur sesuai Peraturan Otoritas Jasa Keuangan.

Para pihak yang terikat dalam suatu perjanjian wajib pula memperhatikan asas-asas perjanjian salah satunya adalah adanya akta perjanjian yang telah disepakati bersama. Dalam hal ini diharapkan bahwa isi perjanjian tersebut betulbetul dilaksanakan oleh para pihak, sehingga tujuan diadakannya perjanjian tersebut dapat tercapai dan terpenuhi sehingga tidak terdapat pihak yang merasa dirugikan. Dalam menghadapi wabah Covid-19 ini pihak debitur juga harus memiliki kesadaran untuk membayar cicilan yang sudah menjadi kewajibannya jika dirasa mampu dan tidak mengalami kesulitan untuk memenuhi kewajibannya pada Bank. Agar suatu perjanjian yang telah dibuat tidak terhambat pelaksanaanya. Perjanjian merupakan hubungan hukum yang mempunyai akibat hukum bahwa kedua orang membuat perjanjian mempunyai hak dan kewajiban, dan apabila salah satu pihak tidak melakukan kewajiban pihak lain dapat menuntut. ${ }^{2}$

Pasal 1132 KUH Perdata mengatur kemungkinan pengecualian pengutamaan terhadap kreditor-kreditor lain. Adapun kreditor yang diutamakan tersebut berdasarkan pasal 1133 KUH Perdata adalah mereka yang memiliki hak-hak yang dilahirkan karena piutang yang diistimewakan (privilege), dari gadai dan dari hipotik. Jenis jaminan yang di pegang kreditor mempengaruhi kedudukan kreditor. ${ }^{3}$

Buku Kedua KUH Perdata mengenai ketentuan jaminan khusus ditentukan besar pinjaman yang nanti diberikan dan agar bunga kembali maka terdapat jaminan benda milik peminjam yang dpat di taksir nilainya dapat di jadikan sebagai jaminan hal ini dapat dilakukan sesuai dengan kesepakatan perjanjian pinjam meminjam dan dapat di dukung dengan perjanjiaan khusus untuk dokumen 
pendukung. Apabila debitor tak mampu membayar, maka benda tersebut dapat di jual untuk dibayarkan kepada yang meminjamkan sebagai gantinya. ${ }^{4}$

Penegakan hukum saat ini juga bukan lagi berdasarkan kesepakatan nilainilai yang telah ditetapkan oleh Pemerintah saja. Dalam rangka mewujudkan tujuan hukum yang jelas fungsi penegakan hukum memiliki posisi yang strategis. Hukum merupakan sub sistem hukum yang tidak berdiri sendiri, melainkan terikat erat dengan keadaan yang sedang terjadi di dalam masyarakat. Proses perwujudan penegakan hukum ke dalam masyarakat diharapkan mampu bersikap adil dan tidak merugikan pihak lain.

Penerapan Ketentuan restrukturisasi di Bank tanpa batasan plafon kredit. Dari kata "dapat" ini mengandung penafsiran bahwa pasal ini bukan mewajibkan, melainkan memberikan pilihan dapat atau tidak dapat memberikan kelonggaran kepada debitur sesuai Peraturan Otoritas Jasa Keuangan. Karena pada kenyataannya wabah Covid-19 mempunyai dampak langsung dan tidak langsung terhadap semua sektor ekonomi bukan hanya debitur tetapi juga kreditur (perbankan).

Setelah berlakunya POJK 11/2020, dijelaskan dalam Pasal 2 ayat (1) dan ayat (2) bahwa Bank dapat menerapkan kebijakan yang mendukung stimulus pertumbuhan ekonomi untuk debitur terdampak Covid-19 dengan cara melakukan reklaksasi atau rekstrukturisasi kredit.

Kemudian, Pasal 5 ayat (1) menerangkan bahwa kualitas kredit atau pembiayaan yang direstrukturisasi ditetapkan lancar sejak dilakukan restrukturisasi. Hal merupakan salah satu upaya Relaksasi Kreadit Saat Pandemi Corona.

Dalam permasalahan ini pemerintah dalam membuat kebijakan-kebijakan baru dalam menghadapi wabah Covid-19 diharapkan memberikan peraturan yang lebih jelas dan mempertimbangkan kemampung perbankan. Dari pihak debitur juga diharapkan tidak memanfaatkan situasi dengan tidak membayar cicilan yang sudah menjadi kewajibannya kepada pihak perbankan. Debitur juga harus memiliki kesadaran untuk membayar cicilan yang sudah menjadi kewajibannya jika dirasa mampu dan tidak mengalami kesulitan untuk memenuhi kewajibannya pada Bank. Karena pada kenyataannya wabah Covid-19 berdapak langsung dan tidak langsung terhadap semua sektor ekonomi.

Penetapan pengaturan ini hanya bank negeri saja yang menerapkannya tidak untuk bank swasta, karena pemerintah hanya menyutik dana untuk bank negeri. Untuk pengajuan relaksasi kredit di utamakan adalah UMKM.

\section{KESIMPULAN DAN SARAN}

\section{Kesimpulan}

POJK No. 11/POJK.03/2020 menjelaskan mengenai uapaya pemerintah dalam meringankan beban masyarakat yang terkena dampak Covid-19 berupa peringanan

\footnotetext{
${ }^{4}$ Riky Rustam, Hukum Jaminan, (Yogyakarta, UII Press, 2017) hal 17
} 
kredit. Peringanan kredit ini untuk masyarakat yang sebelumnya harus mengajukan permohonan peringanan terlebih dahulu pada pihak bank. Peringanan berupa penurunan suku bunga, menambah fasilitas kredit dan konversi kredit menjadi penyertaan modal, memperpanjang waktu kredit, penguranfi pokok kredit, menambah fasilitas kredit dan mengurangi tunggakan bunga kredit.

Permasalahan ini pemerintah dalam membuat kebijakan-kebijakan baru dalam menghadapi wabah Covid-19 diharapkan memberikan peraturan yang lebih jelas dan mempertimbangkan kemampuan perbankan. Kata dapat di gunakan sebagai pilihan untuk melakukan atau tidak melakukan restrukturisasi kredit tersebut. Ini hanya berlaku pada Bank Negeri saja pengaturan untuk Bank Swata tidak berlaku. Karena dalam melakukan penambahan modal pemerintah hanya memberikan pada bank swasta.

\section{Saran}

Dalam hal ini pemerintah harus memberikan kepastian hukum sebagai upaya perlindungan hukum dan penegakan hukum. Pemerintah diharapkan dengan tegas memberikan kepastian kepada pihak Bank kebijakan tersebut wajib dilaksanakan, dan memberikan persyaratan yang jelas, terperinci dan mempermudah persyaratan kepada debitur jika memang membutuhkan kelonggaran pembayaran cicilan kredit. Agar tidak hanya bank tertentu saja yang dapat menyelenggarakan relaksasi kredit tersebut namun seluruh bank. Apabila di bentuk peraturan yang menegaskan keharusan bank memberikan relaksasi kredit dalam pengaturan tersebut juga di beru pengaturan mengenai pemberian sanksi kepada bank yang sudah di suntik dana oleh pemerintah apabila tidak terdapat program relaksasi kredit.

\section{DAFTAR PUSTAKA}

Bambang Waluyo, Penelitian Hukum Dalam Praktek, (Jakarta: Sinar Grafika, 2002)

Rendra, Tinjauan Yuridis Terhadap Fidusia Ulang Objek Tanpa Roya Fidusia Berdasarkan Undang - Undang Nomor 42 Tahun 1999 Tentang Jaminan Fidusia. Jurnal Volume II, 2015

Riky Rustam, Hukum Jaminan, (Yogyakarta, UII Press, 2017)

Siti Nurhalimah, Covid-19 dan Hak Masyarakat atas Kesehatan, SALAM; Jurnal Sosial \& Budaya Syar'i FSH UIN Syarif Hidayatullah Jakarta, Vol. 7 No. 6 (2020), pp. 543-554, DOI: 10.15408/sjsbs.v7i6.15324

Wirjono Prodjodikoro, Asas - Asas Hukum Perjanjian, Mandar Madju, Bandung, 2000

Kitab Undang-Undang Hukum Acara Perdata

Peraturan Otoritas Jasa Keuangan Republik Indonesia Nomor 11/POJK.03/2020 Tentang Stimulus Perekonomian Nasional Sebagai Kebijakan Countercyclical Dampak Penyebaran Coronavirus Di Sease 2019 